\title{
Çeviriden Beklentiler ve Çeviri Gerçekleri: Çeviri Eleștirisinde Yapıcı Bir Yaklaşım Mümkün Mü?
}

\section{Expectation vs. Reality in Translation: Is a Constructive Approach Possible in Translation Criticism?}

\author{
Merve Sevtap Süren ${ }^{1}$ (1)
}

'Doktora Öğrencisi, İstanbul Üniversitesi, Çeviribilim Doktora Programı, İstanbul, Türkiye

\section{ORCID: M.S.S. 0000-0001-6888-391X}

Sorumlu yazar/Corresponding author: Merve Sevtap Süren (Doktora Öğrencisi), İstanbul Üniversitesi, Çeviribilim Doktora

Programı, İstanbul, Türkiye

E-mail: ilginmerve@gmail.com

Başvuru/Submitted: 19.11 .2021

Kabul/Accepted: 10.01 .2022

Atıf/Citation: Suren, M.S. (2021). Ceviriden beklentiler ve çeviri gerçekleri: çeviri eleştirisinde yapıcı bir yaklaşım mümkün mü? Istanbul Üniversitesi Çeviribilim Dergisi - Istanbul University Journal of Translation Studies, 15, 93-109.

https://doi.org/10.26650/iujts.2021.1026155 öz

Çeviri eleştirisi hem yayıncılık sektörünün hem de çeviribilim alanının en tartışmaya açık meselelerinden biridir. Çeviri eleştirisinin olması gerektiği kadar yapılmıyor oluşunun yanı sıra akademik yayınlarda, edebiyat dergilerinde veya sosyal medyada yer alan sayılı çeviri eleştirisinin niteliği de tartışma konusudur. Çeviri eleştirisinin daha iyi çeviri metinlerin üretilmesini sağlayacak yapıcı bir araç olarak kullanılabileceğini öne süren ve daha fazla çeviri eleştirisi yazılması gerektiğini savunan bu çalışmada öncelikle okurların çevirileri nasıl değerlendirmeleri gerektiği Lawrence Venuti'nin görüşleri ışığında tartışılmıştır. Daha sonra, çeviri eleştirisinin gerek edebi üretimi gerek akademik düşünceyi geliştirmek için yararlı bir yol olduğu düşüncesiyle Vladimir Nabokov ve Lawrence Venuti'nin farklı çeviri ve çeviri eleştirisi yaklaşımları ele alınmıştır. Nabokov örneğinde bir çevirmen olarak çeviri gerçeklerini göz önüne almayan bir çeviri eleştirisi yaklaşımı sergilenirken, Venuti örneğinde çeviri gerçekleri göz önünde bulundurulduğunda bir çeviri hatasından çeviribilim alanında başka çalışmalara da ilham olabilecek fikirler üretilebildiği gösterilmiştir. Birbirinden farklı yaklaşımların benimsendiği ortaya konan bu iki örnek üzerinden çeviri eleştirisinin yapıcı bir araç olarak kullanılabileceği öne sürülmüştür.

Anahtar kelimeler: Çeviri eleştirisi, çeviri gerçekleri, çevirmenin rüyası, sözsel ruhgöçü, Vladimir Nabokov, Lawrence Venuti

\section{ABSTRACT}

Translation criticism is one of the most controversial topics in the publishing sector and translation studies. Although there is a dearth of research papers on translation criticism, even the few articles on translation criticism that have been published in academic journals, literary magazines, and social media are controversial. This study suggests that translation criticism can be used as a constructive tool for the production of better translations. Therefore, it encourages writers to pen more articles on translation criticism. The study focuses on Lawrence Venuti's views on the best practices for reading and reviewing translated texts. Furthermore, it explores Vladimir Nabokov and Lawrence Venuti's approaches to translation and translation criticism in relation to the idea that translation criticism is a useful way to boost literary production and 
academic concepts. Although Nabokov's approach to translation criticism does not consider the ground realities of the translation process, Venuti's approach shows when translation realities are reckoned, a translation error may even lead the way for novel theories; in turn, these theories may inspire the emergence of more works in the field of translation studies. This study considers the approaches by Nabokov as well as Venuti. Through these different approaches, we argue that translation criticism can be used as a constructive tool.

Keywords: Translation criticism, translation realities, translator's dream, verbal transmigration, Vladimir Nabokov, Lawrence Venuti

\section{EXTENDED ABSTRACT}

Translation criticism is one of the most controversial topics in the publishing sector and translation studies. However, the existing body of literature on translation criticism is insufficient. Moreover, even the few existing papers on translation criticism that have been published in academic journals, literary magazines, and social media are controversial in nature. This study suggests that translation criticism can be used as a constructive tool for the production of better translations. It also aims to encourage authors to contribute to the existing literature on translation criticism.

Because readers of translated works may be perceived as the first reviewers and critics of the texts, they must be aware of translators' responsibilities as well as the end-to-end translation process. Therefore, the first topic of discussion in the study is based on Lawrence Venuti's views on the best practices for readers to read and review translated texts. I believe that Venuti's essay titled "How to read a translation" could be viewed as a manifestation of or call for resistance to the policies that prevail in the publishing sector and that render both translations and translators invisible. Should the readers consider Venuti's suggestions while reading translated texts, they might help change the unfair policies in the sector and also contribute to the production of better translations in the future.

Following this discussion, Vladimir Nabokov and Lawrence Venuti's different approaches to translation and translation criticism are explored to show a contrast of attitudes towards translation. Although this comparison may come across as unconventional, Nabokov and Venuti's different approaches to translation errors could be used as two striking examples. Despite being a translator, Nabokov expressed overbearing views on translations and translators. He had impossibly high expectations from translated texts and their translators; however, he did not seem to have considered the realities of the translation process while expressing his opinions. Thus, he criticized the translations of Pushkin's Onegin severely.

However, in his essay "The difference that translation makes: the translator's unconscious," translator and translation studies scholar Lawrence Venuti elaborates on a translation error, which is easy to overlook. In his constructive approach to this translation error, Venuti connects this error to the translator's unconscious, fueling a fruitful discussion on psychoanalytic approaches in translation studies. 
In the case of Nabokov's approach, we observe a translation criticism approach that does not consider the ground realities of the translation process; however, with regard to Venuti's approach, we observe that when translation realities are considered, a translation error may lead a researcher to adopt a viewpoint that might develop a fruitful discussion and even inspire future research in translation studies. With a consideration of these approaches, it may be argued that translation criticism can act as a constructive tool to boost literary production and academic studies. 


\section{Giriş}

Çeviri eylemi yapılmaya başlandığından bu yana çeviriye ve çevirinin nasıl yapılması gerektiğine ilişkin söylemlerin de üretilmeye başlandığı öne sürülebilir. Çeviri konusunda hemen hemen herkesin bir görüşü vardır. Özellikle internet kullanımının, dolayısıyla da insanların görüşlerini paylaştığı forum niteliğindeki sayfaların ve sözlüklerin, kitap satış sitelerindeki yorum bölümlerinin ve en önemlisi de sosyal medya uygulamalarının kullanımının artmasıyla yayıncılık sektöründeki çeşitli aktörlerden sıradan okura kadar pek çok kişinin edebiyat çevirileri hakkında fikir yürüttüğünü görebiliriz. Bu durum çeviri eserlerin görünürlüğünü artırdığı gibi çevirmenlerin görünürlüğünü de bir nebze artırmıştır. Fakat bu görünürlüğün okurlara çeviri eserleri değerlendirmekte ne denli yol gösterici olduğu, çevirmenlere hak ettikleri değerin verilmesini ne ölçüde sağladığı merak konusudur. Çevirilere dair nesnel bir değerlendirme yapıldığını söylemek ise mümkün değildir. Okurlar kendilerine özgü çeşitli sebeplerle birtakım yayınevlerinin, birtakım çevirmenlerin çevirilerini diğerlerine tercih eder, çevirileri ister istemez kendi kafalarındaki birtakım kıstaslara göre değerlendirirler. Nitekim onları daha bilinçli bir yaklaşım benimsemeye yönlendirecek çeviri eleştirilerine pek rastlanmaz. Çeviri eserler ancak kitap tanıtım yazılarında karşımıza çıkar. Bu yazılarda ise kişisel beğenilerin öne çıktığı, çevirilerin nesnel gerekçeler öne sürülmeksizin "iyi” veya "kötü”, "ustalıklı" veya "acemi işi”, "yetkin” veya "beceriksiz" gibi sıfatlarla nitelendirildiği görülür.

Çeviri eleştirisi gerek yayıncılık sektörü gerekse çeviribilim alanı için hassas bir konu izlenimi yaratmaktadır. Çeviribilim alanında pek çok farklı çeviri eleştirisi yöntemi görmek mümkünken çeviri eleştirisinin ne olduğu ve ne olması gerektiği konusunda bir fikir birliğinden bahsetmek olanaksızdır. Çeviri etkinliklerinin yoğun olarak yapıldığı 1940’lı yıllardan günümüze dek, çeviriyle akademik ve/ya da profesyonel anlamda ilgilenen pek çok isim (örn. Hızır 1943; Paker 1983; Göktürk 1986; İnce 1993; Karantay 1993; Aksoy 2001; Yücel 2007; Ece 2008; İnce 2019) çeviri eleştirisinin nasıl yapılmaması gerektiğine değinen, çeviri eleştirisi yapılırken nasıl bir yaklaşım benimsenmesi gerektiğini ortaya koyan yazılar kaleme almışlardır. Farklı isimlerin farklı tarihlerde yazdıkları bu yazıların ortak noktası çeviri eleştirisinin yalnızca özgün metin ve çeviri metin karşılaştırılarak yapılacak kusur bulma amaçlı bir inceleme olmadığg, ancak yapılan çoğu eleştirinin bu şekilde gerçekleştirildiği, dolayısıyla da çevirinin doğasını anlamaktan uzak olduğu görüşüdür. Yukarıda değinilen araştırmacı ve edebiyatçılarınkine benzer bakış açılarını ortaya koyan daha pek çok yazıya ve çeviribilim alanında çeviri eleştirisi üzerine yapılmış akademik çalışmalara rağmen çeviri eleştirisinin günümüzde hâlâ gereğince yapılmıyor oluşu dikkat çekicidir. Yalnızca edebiyat dergilerinde ya da sosyal medyada karşılaşılan eleştirilerde değil, kimi akademik dergilerde yer alan çalışmalarda da çeviri eylemine ilişkin gerçeklerin pek göz önünde bulundurulmadığı, kaynak ve erek metinlerden alınan sınırlı sayıdaki örnekler yan yana koyulup karşılaştırılarak çevirmen kararlarının cımbızlanarak adeta bir hata avcısı tavrıyla didiklendiği, bu süreçte bütünlüklü bir yaklaşım sergilenmediği, "acaba çevirmen neden bu kararı almış olabilir?” sorusunun sorulmadığı anlaşılmaktadır. 
Oysa çeviri eleştirisi “çevirinin doğasının kavranmasını sağla[yabilir], çevirmenin hangi dilsel ve kültürel kısıtlamalar altında çalıştığını irdele[yebilir], bunun sonucunda da çeviriden beklentilerimizin daha gerçekçi bir biçimde oluşturulmasına katkıda bulun[abilir]” (İnce 2019). Bir başka deyişle, çeviriye ilişkin gerçekler göz önünde bulundurularak nesnel ve bütünlüklü bir yaklaşımla yapılacak çeviri eleştirileri hem çeviri üzerine yeni ve yapıcı tartışmaların ortaya çıkmasına, hem daha iyi çeviriler yapılmasına, hem de çevirilerin ve çevirmenlerin daha görünür olmasına yarayacaktır.

Edebiyat çevirmenleri çeviri sürecinin farklı aşamalarında okur, eleştirmen, yazar ve editör gibi farklı kimliklere bürünür, çevirecekleri metinle bu kimliklerle farklı boyutlarda ilişkiler kurarlar; '[b]u kimlikler arasında 'okur' ve 'eleştirmen' kimlikleri daha çok özgün metnin yorumlanma sürecinde öne çıkarken 'yazar' kimliği özgün metnin farklı bir dilde yeniden yaratıldığg 1 süreçte, 'eleştirmen' ve 'editör' kimlikleri de tamamlanmış çevirinin yayınevine sunulmadan önce çevirmenin kendisi tarafından gözden geçirilmesi sürecinde öne çıar” (Ece 2016: 57). Çeviri eleştirisi yapma sürecini göz önüne alırsak, bu işi yapmaya soyunan bir kişinin de eleştireceği çeviriyi incelerken buna benzer biçimde farklı kimliklere bürünmesi olağandır. Bu durumda çeviri eleştirisi yapan kişi erek ve kaynak metinleri karşılaştırmalı olarak değerlendirirken çeviri metne yalnızca "eleştirmen” değil, "okur” ve “çevirmen” kimliğiyle de yaklaşacak, çevirmen kararlarını bu gözle yorumlayacaktır. Çeviri eylemini tüm gerçekleriyle göz önüne alan nesnel ve bütünlüklü bir eleştirinin ancak böylesi bir eleştiri sürecinin sonunda ortaya çıkabileceğini savunmak yanlış olmaz.

Hem çeviri okurlarını hem de çeviri araştırmacılarını çeviri eleştirileri üzerine düşündürmeye ve fikir üretmeye davet etmeyi amaçlayan bu çalışmada önce edebiyat çevirisiyle profesyonel anlamda da uğraşan çeviri kuramcısı Lawrence Venuti'nin okurların çeviri metinleri nasıl okuması gerektiği üzerine önerilerini paylaştığ "How to Read a Translation" (2013) başlıklı yazısı ışığında okurların bilinçli birer "çeviri metin okuru”, diğer bir deyişle "eleştirmen-okur" olmak için neler yapabileceğine değinilecek; daha sonra yazar-çevirmen Vladimir Nabokov'un ve çeviribilimci-çevirmen Venuti'nin birbirine zıt görünen yaklaşımları üzerinden çeviri eleştirisinin nasıl daha yapıcı ve verimli bir hale getirilebileceği tartışılacaktır.

\section{Bir Çeviri Nasıl Okunur - Bir Çeviri Okuru Nasıl Olunur}

Lawrence Venuti'nin “How to Read a Translation” (2013) başlıklı yazısı yayıncılık dünyasına hâkim olan ve çeviriyi ve çevirmenleri görünmez kılan politikalara karşı okurlara yaptığı bir direniş çağrısı, bir manifesto olarak da okunabilir. Venuti'nin bu makalede yaptığı çağrı sıradan okurları hedefliyor olsa da çeviri eleştirisi yapacak kişiler için de yol gösterici olabilir. Nitekim yukarıda belirtildiği üzere, tıpkı çeviri süreci gibi çeviri eleştirisi süreci de bu işi üstlenen kişinin okur - çevirmen - eleştirmen gibi farklı kimliklere bürünmek durumunda kaldığı karmaşık bir süreçtir. Dolayısıyla Venuti’nin çeviri okurlarını gözeterek yaptığı önerilerin çeviri eleştirisi işine soyunan sıradan okur kadar profesyonel eleştirmen ve akademisyenler için de yol gösterici olacağı söylenebilir. 
Bir çevirinin her şeyden önce bir çeviri metin olarak, bir başka deyişle, kaynak metinden ayrı, başlı başına farklı bir metin olarak okunarak değerlendirilmesi gerekir; bu da en başta çevirmenin kim olduğunu ve nasıl bir iş yaptığını anlamayı gerektirir. Bu nedenle Venuti en başta çevirmenin kim olduğunu ve yaptığı işi tanımlamıştır: "çevirmen kaynak metin yazarının dublörü ya da vantriloğu değil, kaynak metni başka bir dil ve kültürde, hatta çoğu zaman başka bir dönemde başka bir kitlenin hoşuna gidecek şekilde yeniden yazan becerikli bir taklitçidir" (2013: 109). Diğer yandan "becerikli bir taklitçi” olarak çevirmenin yapmayı üstlendiği iş ise "telafisi olanaksız bir kaybı fahiş bir kazanç yaratarak telafi etme çabası"dır (a.g.e.: 110). Çevirideki kayıplar, çeviri metni kaynak metinle karşılaştırmayan sıradan okur için görünmezdir; kazançlar ise, okur bakmayı seçtiği takdirde, apaçık ortadadır. Fakat yayıncılar, editörler ve eleştirmenler okurları kolay okunan, bu yüzden de çeviri değilmiş izlenimini yaratan çevirileri tercih etmeye sevk ettikleri için okurlar bu kazançları görmezler. Çeviri değilmiş izlenimini yaratan çevirileri tercih etme eğilimi akıcılıktan yanadır; akıcılık ise standart dil kullanımına, erek dilin en tanıdık gelen biçimine, bir başka deyişle özgün metin okuyormuşuz illüzyonunu yaratmakta en başarılı olan dil kullanımlarını tercih ederek yakalanır. Okur, okuduğu metnin çeviri olduğunu ancak standart dışı bir kullanımla, aşina olmadığı bir sözcükle, bir kullanım hatasıyla ya da anlamsal bir karışıklıkla karşılaştığında fark eder. Çoğu okur bu gibi durumları çevirmenin kusuru olarak yorumlama eğilimindedir. Ne var ki akıcı okuma deneyimini tökezleten bu gibi “aksamalar” çoğu zaman kaynak metnin dilsel ya da biçemsel özelliklerinden ileri gelmekte ve ardında pek çok karmaşık süreci ve çeviri kararını barındırmaktadır. Venuti'nin okurlara yaptığg ilk çağrı tam da bununla ilgilidir: “Okurken yalnızca anlamı değil, dili de göz önünde bulundurun; çevirinin biçimsel özelliklerini de değerlendirin” (a.g.e.: 110). Venuti bu ilk çağrıyla okurdan çevirinin ve çevirmenin akıcılık illüzyonuyla görünmez hâle gelmesine ya da tam aksine çevirinin ve çevirmenin ancak akıcılık illüzyonu kaybolduğunda görünürlük kazanmasına direnç göstermesini bekler. Okur, çevirmenin kendine özgü söyleyiş ve ifade gücünü, kendi biçemindeki özgünlügü, metindeki karakterlere özgün seslerini veren ve karakterlerin psikolojik hatlarını çizen dilsel incelikleri fark edebilmelidir. Çevirmen taklitçidir çünkü kaynak metni erek dilde taklit eder; ancak çeviri metinde yer alan her sözcüğü çevirmen seçmiştir ve onun seçimlerinin kaynak metin yazarının seçtiği dili de aşabilen etkileri olabilir. Venuti ikinci çağrısıyla buna dikkat çeker: "Çevirilerin yalnızca mevcut standart dilde yazılmasını beklemeyin; dilsel değişkenliklere açık olun” (a.g.e.: 111) çünkü çevirmenin dokunuşları erek dilde yaygın kullanılan biçimlerden sapmalarda kendini gösterir. Eski veya yeni ifadelerin kullanımı, argo ve küfürler, toplumsal ve yöresel ağızlar, jargonlar ve yabancı sözcükler gibi dilsel özellikler söz konusu dile özel oldukları için başka dillere aktarılmaları zor olduğundan, erek dilde tuhaf gelen dilsel değişkenlikler çevirmenin kaynak metni farklı bir kültüre taşımak için nasıl bir strateji geliştirdiğini ortaya koyar. Venuti bundan sonra okurları daha derinlikli bir okuma yapmaya çağırır: "Çağrışımları ve kültürel göndermeleri göz ardı etmeyin; onları da bir diğer ilişkili anlam katmanı olarak okuyun” (a.g.e.: 112). Yayıncılık sisteminin görünmez kıldığı ve yaptığı iş çoğu zaman kolaylıkla gözden kaçan çevirmenin dili, erek kültürde hâlihazırda var 
olan biçemler, türler ve metinlerle de ilişkiler kurarak çok daha derin kökler salabilir. Bir başka deyişle çeviri metin, kaynak metinde var olmayan bambaşka metinlerarası ilişkiler kurabilir ve bu sayede söz konusu eserin saygınlığını erek dilde daha da pekiştirebilir.

Diğer yandan çevirmen iki metin arasında anlam örtüşmesi sağlamak adına ne kadar çabalasa da hiçbir çeviri kaynak metni erek dile doğrudan, sorunsuz bir biçimde aktaramaz. Hiçbir çeviri, çeviri metnin okuruna, kaynak dil okurunun kaynak metinle yaşadığı deneyime yaklaşabilecek bir okuma deneyimi sağlayamaz. Böyle bir okuma deneyiminin sunulabilmesi için erek okura kaynak dil, kaynak edebiyat ve kaynak kültüre yaşam boyu maruz kalmışlığın aktarılması gerekir, ki bu da imkansızdır. Bir çevirmen ne kadar yaratıcı olursa olsun, okurun ait olduğu dil topluluğunu ya da kültürel kimliğini değiştirmesi mümkün değildir. Bu nedenle çevirmenin özel bir tür yazar olarak kabul edilmesi gerekir; bu özel yazarın, kaynak metin yazarının özgünlüğüyle rekabet etmesi değil, erek dilin yazınsal kaynaklarından istifade eden bir biçemsel repertuarın yardımıyla taklit sanatındaki becerisini sergilemesi beklenmelidir. Çeviri, kaynak metnin kendisini değil, çevirmenin o metni nasıl yorumladığını aktarır; dolayısıyla da çevirmenin kaynak metni oluşturan dil ve kültür farklılıklarını yorumlayacak kadar uzman ve kendi yorumunu erek dilde aktaracak kadar yenilikçi olması gerekir. Örneğin bir çevirmen halihazırda çevrilmiş olan bir klasik eseri yeniden çevirdiğinde, çevirmenin bu yeni çeviriyi gerekçelendirmek adına çeviride yeni bir şeyler sunmuş olması, hatta ortaya koyduğu yeniliği betimleyebilmesi beklenir. Çevirmenler genellikle gerekçelendirmelerini çevirilerine yazdıkları önsözlerde açıklarlar, fakat çeviri metin okuma bilincine sahip olmayan okurlar önsözleri es geçme eğiliminde olabilmektedir. Venuti'nin bir sonraki çağırısı da buna işaret eder: "Çevirmenin yazdığı önsözü es geçmeyin; çeviriye kılavuzluk ettiği ve onu eşsiz kılan şeyin beyanı olduğu için önce onu okuyun" (a.g.e.: 114). Bir çevirmeni en görünür k1lan unsurlardan biri olarak çevirmen önsözlerini okumak okurların çevirmenin yaklaşımını görüp çeviriyi buna göre değerlendirmesini sağlayacaktır.

Okurun bilinçli bir biçimde görmesi gereken yalnızca çevirmenler değildir, kaynak kültürün de erek okur için görünür olması gerekir. Ancak özellikle çeviri eser üretiminin basılan kitapların ancak \%2-4'ünü oluşturabildiği anglosakson yayıncılık dünyası başta olmak üzere, kültürel ya da finansal çıkarların ön planda tutulduğu yayıncılık yaklaşımlarının hüküm sürdügü kültürlerde yabancı edebiyatlar yeterince temsil edilmezler. Bu temsil sorunu başka kültürlere ilişkin kimi yanıltıcı basmakalıp düşünceleri de beraberinde getirebilir. Venuti bu yazıdaki son çağrısıyla okurlardan söz konusu temsil sorununa karşı durmalarını ister: "Tek bir çeviriyi bütün bir yabancı edebiyatın temsilcisi olarak görmeyin; aynı dilden yapılan diğer eserlerin çevirileriyle karşılaştırın" (a.g.e.: 114). Yapılan tek tük çeviriler doğal olarak kaynak kültürü temsil etmekte eksik kalacaktır. Oysa okurlar aynı dilden farklı yazarlar okuyarak kaynak kültür koşullarını daha geniş bir bakış açısıyla değerlendirebilirler. Hatta Venuti’ye göre okurlar bakış açılarını komşu dilleri ve bölgeleri de kapsayacak şekilde geniş tutmalıdır. Çeviri edebiyatları böyle bilinçli bir biçimde ele almak, siyasi ayrılıklara ve askeri çatışmalara dahi yol açan kültürel farklılıkların anlaşılmasına katkıda bulunabilir. 
Sonuç olarak, Venuti'nin çeviri metinlerin nasıl okunması gerektiğine ilişkin okurlara verdiği önerileri çeviri ve okuma süreçlerini de göz önüne alarak özetlersek, çeviri eleştirisi yaparken başvurulabilecek adımları şu şekilde sıralayabiliriz:

- Akıcılığı bozacak nitelikte standart dışı bir dil kullanımıyla karşılaştığınızda bunun olası nedenlerini sorgulayın.

- $\quad$ Farklı ağız ve lehçelere ait ifadeler, argo ve küfürler, arkaik ve yeni sözcükler gibi dilsel değişkenliklere açık olun.

- Çeviri metindeki çağrışımlara ve kültürel göndermelere dikkat edin.

- Çevirmen önsözleri, sonsözleri ve dipnotlarını göz önünde bulundurun.

- Belli bir kültürün edebiyatına ait çeviri eserleri birlikte değerlendirin.

Eleştirmen-okurlar çeviri metinleri okurken bu adımları göz önünde bulundururlarsa yalnızca çevirilere dair çeviri gerçeklerini göz önüne alan, dolayısıyla da daha ayakları yere basan fikirler edinmekle kalmayacak, forumlarda, sözlüklerde, kitap satış sitelerinde ve sosyal medyada yaptıkları yapıcı eleştirilerle daha iyi çeviriler üretilmesine katkıda bulunmuş olacaklardır.

\section{İki Çevirmen-Eleştirmenden İki Çeviri Eleştirisi Yaklaşımı}

Sıradan okurların çeviri eserlere ilişkin yapıcı eleştiri ve yorumlarının yanı sıra, çevirilerin ve çevirmenlerin gelişimine katkıda bulunacak bir diğer şey de akademik yayınlarda ya da edebiyat dergilerinde yayımlanacak "profesyonel” çeviri eleştirileri ve inceleme yazılarıdır. Bilinçli bir yaklaşımla kaleme alınacak bu gibi eleştiri yazılarının hem akademik alana hem de yayıncılık sektörüne ne gibi katkılarda bulunabileceği iki çarpıcı eleştiri örneği üzerinden tartışılabilir. Bu örneklerden ilki Rus asıllı Amerikalı yazar-çevirmen Vladimir Nabokov’un çeviri yaklaşımı ve bu yaklaşım ışığında şekillendirdiği çeviri eleştirisi, diğeri ise Amerikalı çeviri kuramcısı ve çevirmen Lawrence Venuti’nin bir çeviri hatası üzerine düşünerek geliştirdiğgi, çeviri eleştirisi olarak da yorumlanabilecek çeviri yaklaşımıdır.

\section{Nabokov'un Yaklaşımı: "Sözsel Ruhgöçü”}

Vladimir Nabokov farklı dillerle ve çeviri metinlerle iç içe bir yaşam sürmüştür. Nabokov henüz yedi yaşındayken ana dili Rusçanın yanı sıra İngilizce ve Fransızca dillerinde de okuyup yazabilmektedir, on dört yaşına bastığında ise Tolstoy'un, Shakespeare'in, Flaubert'in tüm eserlerini okumuştur. Dört dil konuşabilen ebeveynlere sahip olmanın yanı sıra, Rus öğretmenler, İngiliz dadılar ve Fransız mürebbiyelerle büyümüştür. Fakat farklı dil ve kültürlerle bu denli haşır neşir olduğu halde Nabokov’un çeviri metinlere temkinli yaklaştığı görülmektedir. Özgün dillerinde okuyamadığı Yunanca, Latince, İspanyolca ve İtalyanca klasiklerin çevirilerini özgün metnin hemen yan sayfada yer alması koşuluyla okumuştur. Japon bir gazeteci Japon edebiyatı hakkındaki düşüncelerini sorduğunda, yapılan çevirilere güvenmediği için bu edebiyattan hiçbir eser okumadığını söylemesi, edebiyat yaşamında kendi eserleriyle olduğu kadar çevirileriyle de dikkat çeken Nabokov'un çeviriye duyduğu güvensizliğe ilginç bir örnektir (Boyd 2010: 5). 
Diğer taraftan Rus yazarı İngilizce dilinde eserler kaleme alan bir yazara dönüştüren şey yine çeviridir. Kitaplarından birinin ilk çevirisini hiç beğenmeyen Nabokov önce metni kendisi İngilizceye çevirmiş, sonra bu kadarla da kalmayıp romanı sil baştan İngilizcede yeniden yazmış, bunun ardından da doğrudan İngilizce bir başka roman kaleme almıştır. Nabokov'un çeviriyle ilişkisi yalnızca kendi eserlerinin çevirisiyle de sınırlı kalmamıştır. Amerika'ya taşındıktan sonra kendisini Rusça yerine İngilizce yazmaya zorlayan yazar, kendini geçindirmek için Rusçadan İngilizceye çeviriler yapmayı sürdürmüştür. Kardeşleri Nabokov'un en ünlü eserlerinden Lolita'yı İngilizceden Rusçaya çevirmeyi denemişlerdir, ancak Nabokov kendisinden başka kimsenin çeviri yetkinliğine güvenmediği için bu işi de bizzat üstlenmeyi tercih etmiştir. Bu örnek Nabokov’un çeviri söz konusu olduğunda hiç kimseye, hatta kardeşlerine bile güvenmediğini göstermektedir (Boyd 2010: 7).

Nabokov, Rus Edebiyatı Dersleri adlı kitabındaki “Çeviri Sanatı” başlıklı yazısında, çeviriyi "sözsel ruhgöçü” (verbal transmigration) olarak tanımlamıştır. Ona göre üç tür kötü çeviri vardır: İlkinde çevirmen cahillik ya da bilgisizlikten kaynaklanan hatalar yapar. İkincisinde metindeki anlayamadığg ya da okurun anlamayacağını veya müstehcen bulacağını düşündüğü kısımları çevirmeden atlar. Üçüncüsünde ise, metni erek okurun hoşuna gidecek şekilde güzelleştirir. Yazara göre bu büyük bir suçtur. Bu suçu "işleyenin, eski zamanlarda intihalcilere yaptıkları gibi boyunduruğa vurularak cezalandırılması gerekir” (2013: 409).

Nabokov çevirmenleri de, "eserlerini takdir ettiği az tanınmış bir dahiyi dünyanın da aynı şekilde takdir etmesini isteyen araştırmacı; iyi niyetli vasat yazar ve yabancı bir meslektaşının ahbaplığıyla ferahlayan profesyonel kalem erbabı" olmak üzere üçe ayırmıştır (a.g.e.: 414). Bir yandan metne sadık kaldı̆̆ını ve titiz çalıştığını umduğu "araştırmacı" çevirmenin yeterince uzun ve ayrıntılı dipnotlar vermeyeceğini öne sürerken, diğer yandan çok çalışıp çok üreten, "köle gibi çalışan" çevirmenin sadakat ve titizlikten ödün vereceğini düşünür. Fakat asıl sorun bu iki tip çevirmenin de yaratıcı yetenek gösteremeyecek olmalarıdır, çünkü Nabokov’a göre bilgi ve çalışkanlık, hayal gücü ve üslubun yerini tutamaz. Bahsettiği üçüncü çevirmen tipi, yani "şair-çevirmen" ise başka çevirmenlerin yaptığı "sözcügü sözcüğüne” çevirilere bel bağlar, çünkü dili bilmiyordur; ya da dili biliyor olsa bile "araştırmacının hassasiyetinden ve profesyonel çevirmenin deneyiminden yoksundur". Şair-çevirmenle ilgili asıl sorun, metni kendi sesine boğarak kaynak metin yazarını kendisi gibi konuşturmasıdır (a.g.e.: 414-415).

Nabokov aynı yazıda ideal çeviri için üç aşamalı bir tarif de vermiştir: Öncelikle bir çevirmenin kaynak metin yazarı kadar yetenekli olması gerekir. Çevirmen hem kaynak hem de erek dil ve kültürü çok iyi bilmelidir. Yazarın gerek biçemine gerekse kullandığı sözcüklerin tüm çağrışımlarına tamamen hâkim olmalıdır. Ayrıca çevirmen taklit yeteneğine de sahip olmalı, kaynak metin yazarının rolüne bürünüp erek dilde "onun davranış ve konuşma alışkanlıklarını, tutumlarını ve düşüncelerini gerçeğe en yakın şekilde taklit edebilmelidir” (a.g.e.: 415).

“Çeviri Sanatı” başlıklı bu yazıda yer verdiği görüşleri özetleyecek olursak, Nabokov’un çevirmenin çeviri sürecinde erek kültürü göz önünde bulundurarak erek okurun hoşuna gidecek 
türden çeviri kararları almasına karşı olduğunu; kaynak metin odaklı bir çeviri yaklaşımı benimsenmesi gerektiğine inandığını, ama diğer yandan ortaya çıkan çevirinin çevirmenin yaratıcı yeteneğini gözler önüne serip edebiyat zevki vermesini de beklediğini söyleyebiliriz. Nitekim buna benzer bir yaklaşım "Problems of Translation: Onegin in English" başlıklı, bu çalışmada bir çeviri eleştirisi olarak okuyacağımız yazısında da apaçık görülmektedir.

Nabokov bölümler halinde kaleme aldığı bu yazının başında, şiir çevirileri üzerine yazılmış incelemelerde "çevirinin su gibi okunduğu"nu söyleyenlere, bir başka deyişle özgün metinden haberi bile olmayan birinin sırf kafiyeli bir metin okuduğu için bir taklidi "okunaklı" olarak değerlendirmesine çok öfkelendiğinden bahseder. Nabokov, "serbest”" çeviriyi üçkâğıtçılık ve zorbalık olarak görür. Ona göre çevirmen eserin "ruhunu" aktarmak niyetiyle işe koyulduğu anda, eserini çevirdiği yazarın onuruna leke sürmeye başlar. İşte bu nedenle en kötü "düz" (literal) çeviri, en güzel "aktarım"dan (paraphrase) bin kat daha iyidir. Nabokov, bundan sonra, belki de eseri ne kadar iyi anladığını ve ona ne kadar hâkim olduğunu göstermek istercesine, nazım biçiminde yazılmış bir Rus romanı olan Onegin'i incelemiştir. Kısa bir karakter, mekân ve tema analizi yaptıktan sonra, Puşkin'in bu romanını eşsiz bir edebiyat eseri haline getiren ve aynı zamanda çevrilmesini de zorlaştıran nazım özelliklerini sıralar. Yazının ikinci bölümünde Rus şiirinin altı dil ve vezin (prosody) özelliğini sayar ve İngilizceyle karşılaştırmak için Wordsworth ve Milton'dan Shakespeare ve Pope'a kadar çeşitli şairlerin dizelerinden alıntılar yapar. Üçüncü bölümde, Rus vatanseverlerin öfkesini çekebileceğini düşündüğü bir iddiada bulunur ve Rusya'nın ulusal şairi Puşkin'in Rus kültürünün olduğu kadar Fransız edebiyatının da ürünü olduğunu ileri sürer. Daha sonra Puşkin'in Fransız etkisiyle Rusçasına kattığı ifadelere örnekler verir ve Puşkin'i İngilizceye çevirecek olan çevirmenin bunları nasıl aktaracağını düşünmesi gerektiğini söyler. Ayrıca, Nabokov’un aktardığına göre, Puşkin pek çok Fransız yazarın eserlerini okumasına ve beğenmesine rağmen, Alman ve İngiliz yazarları okumamıştır. Shakespeare ve Byron gibi yazarların eserlerini Fransızcalarından okumuş, Byron'ı ise kendisi için Fransızcaya çevirmiştir. Nabokov yazının dördüncü bölümünde şiir çevirisini mümkün kılacak yöntemin ne olduğunu ortaya koyar. Bir başyapıtı bir başka dile aktarmak isteyen kişinin tek görevi, söz konusu metni mutlak bir kusursuzlukla yeniden üretmektir. Bunun yolu “düz” çeviri yapmaktan geçer. Düz çeviri dışında bir yöntem kullanılarak üretilen metin bir çeviri değil ancak bir taklit, uyarlama ya da parodi olabilir.

Nabokov bu noktada önemli bir soru sorar: Bir çeviri, özgün metni bir başka dile mutlak sadakatle aktarırken aynı zamanda özgün metnin biçemini, ritmini ve uyağını da koruyabilir mi? Kendi dilinin sınırlarından çıkmamış bir sanatçı biçem ve içeriğin iki ayrı şey olarak görülmesini ve bunlardan biri aktarıldığında diğerinin aktarılamayacağı düşüncesini şaşırtıcı bulabilir. Özgün metin sözsel varlığından yoksun bırakıldığında ilk ihtişamını taşımayacaktır, ancak yine de düzgün bir şekilde parçalarına ayrılıp tekrar birleştirilebilir ve tüm organik detaylarıyla bilimsel olarak incelenebilir. Nabokov bu sorgulamanın ardından gelen beşinci bölümde Onegin'in pek çok dile yanlış çevrildiğini öne sürerek, metnin Fransızca, İngilizce ve 
Almanca çevirilerini değerlendirir. Bu çarpıcı çeviri eleştirisine bakılırsa, bu çeviriler arasında en kötüsü Almanca çevirilerdir; Fransızca çeviriler ise diğerlerine nazaran bir nebze daha iyidir. Nabokov bu yorumların ardından eserin dört İngilizce çevirisini değerlendirir ve bu çevirilerin "sözümona çevirmenler"inin en büyük sorunlarından birinin cehalet olduğunu söyler. Nabokov’a göre Onegin gibi bir metnin çevirisini yapmaya soyunacak kişinin başlica kimi metinleri okumuş olması, kimi önemli bilgilere sahip olması gerekir. Yazının altıncı bölümünde Puşkin çevirmenlerinin farkında olması gereken önemli noktaları vurgulamak için romanın bir bölümünü otobiyografik özellikler gösteren ayrıntılara ve sözcük çağrışımlarına değinerek detaylı bir biçimde irdeler ve bütün bunları göz önünde bulundurarak yaptığı kendi çevirisini paylaşır. Ardından metni bütün bu ince detayların farkında olmadan İngilizceye çevirmiş olan çevirmenlerin hatalarını tek tek inceler. Yedinci ve son bölümde ise şu sonuca ulaşır:

1. Onegin eserini uyaklı bir şekilde çevirmek imkânsızdır.

2. Metnin kiplemeleri, uyakları, tüm çağrışımları ve dikkate değer özellikleri bir dizi dipnotla açıklanabilir.

3. Onegin'in her kıtasındaki uyaklı ve dört vezinli on dört mısra, çeşitli uzunluklarda uyaksız iki ya da beş vezinli on dört mısra hâlinde çevrilebilir.

Nabokov kendi çarpıcı çeviri ve çeviri eleştirisi yaklaşımını sergileyen bu yazıyı bitirirken, çevirilerde açıklama ve sonsuzluk arasında tek satırlık bir aralık bırakacak kadar müthiş uzunluklarda dipnotlar, özgün metni ne eksilten ne de yücelten, uyakla kirletilmemiş "düz” aktarımlar görmek istediğini vurgular. Ayrıca kendi Onegin çevirisinde bu kıstaslara harfiyen uyacağını, aksi takdirde bu çeviriyi asla ortaya çıkarmayacağını belirtir. Gerçekten de Nabokov'un 250 sayfa uzunluğundaki Onegin çevirisine 1500 sayfa uzunluğundaki notlar eşlik etmektedir. Bir şiir üzerine kaleme alınmış en uzun açıklama olma özelliğini de taşıyan bu İngilizce notlar, Rus akademisyenler için Rusçaya da çevrilmiştir (Boyd, 2010: 6). Fakat 1964 'te yayımlanan bu çarpıcı çeviri yirminci yüzyılın en sert edebiyat tartışmalarından birine neden olur. Nabokov'un bu ilginç çeviri yaklaşımını destekleyenler olduğu kadar sertçe eleştirenler vardır. Ancak Nabokov'un bu sert eleştirilere cevabı, tartışmalı çevirisini elden geçirip daha da "düz" bir hâle getirmek olur (a.g.m.: 12).

Nabokov kendi Onegin çevirisine yazdığı önsözde bir şiirin başka bir dile aktarılmasının üç yöntemi olduğunu belirtmiştir:

1. Açımlamacı (Paraphrastic): Bu yöntem, özgün metnin biçimden kaynaklanan gerekliliklerden, tüketiciye atfedilen geleneklerden ve çevirmenin cehaletinden ileri gelen eksiltme ve eklemelerin yer aldığı bir serbest versiyonunu sunar. Bu yöntemle çevrilmiş kimi şiirler üslup diksiyonu (stylish diction) ve deyişsel kısalığın (idiomatic conciseness) cazibesine sahip olsa da hiçbir zaman üslupçuluğa teslim olunmamalı ve hiçbir okur bu yönteme kanmamalıdır.

2. Sözlüksel (Lexical): Bu yöntem sözcüklerin temel anlamını ve sözcük dizilişini birebir aktarır. Bu işlemi iki dilli ve zekâ sahibi herhangi birinin idaresindeki bir makine bile yapabilir. 
3. Düz (Literal): Bu yöntem bir diğer dilin çağrışımsal ve sözdizimsel olanaklarının izin verdiği ölçüde, özgün metnin kesin bağlamsal anlamını olabildiğince yakın bir biçimde aktarmaktır. Nabokov’a göre yalnızca bu “doğru” çeviridir [1990: vii-viii].

Nabokov Onegin'i çevirirken benimsediği çeviri yöntemini şöyle açıllar: "Eugene Onegin'i Puşkin'in Rusçasından benim İngilizceme aktarırken, 'beşli' (iambic) hece ölçüsü de dahil olmak üzere bütün biçimsel öğeleri sadakate engel oldukları her yerde anlamın tamlığına feda ettim. O leziz taklidin doğruluğa yeğlediği her şeyi (zarafet, ses uyumu, açıklık, zevklilik, modern kullanım ve hatta dilbilgisini) kendi düz [çeviri] idealime feda ettim. Puşkin çevirmenleri uygarlığın posta istasyonlarında değiştirilen atlara benzetmişti. Benim düşünebildiğim en büyük mükafat ise öğrencilerin çalışmamı bir midilli gibi kullanabilecek olmasıdır” (Nabokov 1990: x).

Görüldüğ̈̈ üzere, çeviri eylemini gerçekleştiren ve çeviri üzerine fikir üreten biri olarak Vladimir Nabokov'un çeviri eserlerden günümüz çeviri gerçekleriyle pek de örtüşmeyen beklentileri ve Onegin'in var olan çevirilerine getirdiği acımasız eleştiriler dikkat çekmektedir. Günümüzde akademik alanda en çok kullanılan çeviri eleştirisi yöntemlerini ortaya koyan Raymond van den Broeck ve Antoine Berman'ın çeviri eleştirisinin beğeni değil bilgi üzerine olması, değerlendirme değil anlamaya yönelik yapılması gerektiğini ifade eden (Broeck 1985: 60, akt. Ece 2008: 142) ve yayıncılık dünyasında edebiyat eleştirisi gibi saygın bir tür olması gereken çeviri eleştirisinin farklı okumalarla çeviri eserleri zenginleştirerek onlara hizmet etmesinin beklendiğini (Berman 1995: 11-97, akt. Ece 2008: 143) vurgulayan görüşleri, çeviri metinler incelenirken benimsenmesi gereken yaklaşımı özetler niteliktedir. Günümüzde her bir çeviri, özgün metnin bir başka okuması, çevirmenin özgün metni yorumlaması olarak kabul edilmektedir. Diğer yandan yayıncılık dünyasında belirli bir zamanda hüküm süren beklentiler, çevirmene sağlanan çalışma koşulları, metnin yayına hazırlanma süreci gibi somut çeviri gerçekleri de ortaya çıkan çeviriyi etkileyen diğer unsurlardır ve çeviri eleştirisi yapılırken bu unsurların da değerlendirilmesi ya da en azından göz önünde bulundurulması gerekir. Bu yaklaşımlar ışı̆̆ında bakıldığında Nabokov'un beklentileri ve eleştirileri daha da çarpıcı ve gerçekdışı bir hale gelmektedir. Nabokov ne yapılan çevirileri söz konusu çevirmenlerin kendi yorumları olarak değerlendirmiş, ne de bu çevirmenlerin çalışma koşullarını ya da çeviriyi etkilemiş olabilecek diğer unsurları göz önünden bulundurmuştur. Dolayısıyla bu beklentiler ve eleştiriler günümüz çeviri gerçeklerine uygun olmadığı gibi, daha iyi çeviriler üretilmesini sağlayacak yapıcı bir yaklaşımdan da yoksundur. Öte yandan çevirmenlere ve yaptıkları çevirilere üstten bakarak dudak bükmek yerine, yukarıda bahsedildiği gibi çeviriyi mümkün olan tüm gerçekleri göz önüne alarak değerlendirerek bilinçli bir okuma yapmak ve çeviri eleştirisi yaparken yapıcı bir yaklaşım benimsemek yalnızca daha iyi çeviriler yapılmasını sağlamakla kalmaz, çeviri araştırmaları açısından da yeni kapılar açabilir.

\section{Lawrence Venuti'nin Yaklaşımı: "Çevirmenin Rüyası"}

Daha önce vurgulandığı üzere, çevirilerde karşılaşılan hataları çevirmenin bilgisizliği ya da yetersizliğinden kaynaklanan dilsel hatalar olarak değerlendirerek kestirip atmak kişinin 
okuma zevkine ket vurmaktan başka bir işe yaramaz. Bu hataların ardında nelerin yatıyor olabileceği üzerine düşünmek ise hem çevirinin doğasına ve çeviri sürecine ilişkin gerçekleri ortaya çıkarmaya, hem de çeviri üzerine düşünce üreterek çeviri araştırmalarının kapsamını artırmaya yarayabilir.

Lawrence Venuti'nin Translation Changes Everything adlı kitabında yer alan “The Difference that Translation Makes: the translator's unconscious" başlıklı makalesinde dikkat çeken bir inceleme buna çarpıcı bir örnek oluşturabilir. Bu makalede çeviribilimde, çevirinin kaçınılmaz olarak ortaya çıkardığı farklılıkları betimleyen, açıklayan ve onların sorumluluğunu üstlenen çeviri araştırması ve uygulaması yöntemleri geliştirmek gibi etik bir amaç benimsenmesi gerektiğini öne süren (2013: 34) Venuti, bu amaç doğrultusunda özellikle yapısalcılık sonrası dil ve metinsellik kuramlarına işaret eder ve dilsel ve kültürel farklılıkları hesaba katmaya çalışan ve bu farklılıkların üzerine en isabetli ve karmaşık şekillerde düşünmemizi sağlayan kuramların bunlar olduğunu vurgular. Bu noktada çeviri metnin maddeselliğine değinen Jacques Derrida'dan bir alıntı yapar. Bu alıntıya göre, kaynak metnin gövdesi, yani onu oluşturan akustik ya da yazıbirimsel gösterenler zinciri açısından maddeselliği, çeviride yeniden üretilemez, daha doğrusu, bu çaba çift yönlü bir kayba neden olur: kaynak metnin eşsiz dokusunu ya da gösterme sürecini oluşturan metiniçi etkilerin kaybına ve kaynak dil okuru için önemli olan metinlerarası ilişkilerin kaybına. Kaynak metnin maddeselliği bir kenara bırakıldığında, çeviri tamamen bağlamsızlaştırıcıdır: söz konusu metnin kurucu bağlamını bozar. Bu bağlamsızlaştırma, bizzat çeviri sürecinin ürettiği ilk farklılıktır (a.g.e.: 35).

Venuti'nin makalesinde yer verdiği ve yukarıda özetlenen alıntının yapıldığı metni Fransızca aslından İngilizceye çeviren kişi Alan Bass’tir. Ancak Venuti’ye göre Bass'in çevirisinde bir hata vardır. Bass çeviride belirsiz tanımlık "un"un yerine gösterme sıfatı "that"i koymuş ve bu "that" ile paragrafın ilk üç cümlesinde geçen kaynak metnin maddeselliğine atıfta bulunmuştur. Ancak "un"u "that" ile değiştirmek hatalıdır, çünkü bu, anlamı değiştirmiştir: Derrida’nın kaynak metnin maddeselliğinin taşınamayacağını söylediği İngilizce metindeki ilk cümle, bu maddeselliğin taşınabileceğini ya da "yeniden kurulabileceğini” söyleyen dördüncü cümleyle çelişmektedir. Venuti' ye göre bu hatanın nedeni yetersizlikle açıklanamaz, zira Bass doktorasını Fransız edebiyatında yapmış ve Derrida'nın dört kitabını İngilizceye çevirmiş yetkin bir çevirmendir. Çevirilerinde açıklayıcı notlara yer vermekte ve kendi yazılarında da Derrida'nın felsefesine ve psikanalize değinmektedir. Ayrıca Bass daha önce yayımlanan çevirilere de başvuran dikkatli bir çevirmendir. Söz konusu makaleyi çevirmek için daha önce Jeffrey Mehlman tarafından yapılan çeviriyi incelemiştir. Fakat Mehlman çevirisi de aynı hatayı, aynı yanlış sözdizimini, hatta aynı ifade şeklini içermektedir (a.g.e.: 38-39).

Venuti’ye göre bu hatalı çeviriler, çevirmenin rüyası denilebilecek şeyi açığa vurmaktadır: yani bir çevirinin hiçbir kayıp ya da kazanç söz konusu olmadan, kaynak metni tamamıyla ve tüm maddeselliğiyle yeniden üretebileceği; çevirinin kaynak metinle diller ve kültürler arasındaki indirgenemez farklılıkları aşacak bir benzerlik gösterebileceği rüyasını. Çeviri, 
çevirmenin bilinçdışının dilsel ve söylemsel yapılardaki değişkenlikler aracılığıyla, yani bir "geriye kalan" (the remainder) aracılığıyla su yüzüne çıktığı bir rüya sahnesidir. Çevirmenin yarattığı gösterme zinciri kaynak metnin içerdiği hiçbir rüyayı çevirmez, onun yerine çevirmenin kendi bilinçdışı arzusunu, belli bir anlam arzusunu, ya da bu durumda, çeviriyle ilgili belirli bir anlam kuramını koyar. Fakat bu arzu örtüktür, ancak sözdizimdeki bir yanlış yorumlama aracılığıyla kendini belli eder (a.g.e.: 39).

Venuti, Bass' in çevirisindeki hatanın Fransızca metnin yanlış okunmasından kaynaklandığını söyler. Okurun metni değiştirmesine ve metinde beklediği ya da zihnini meşgul eden bir şeyi okumasına, bir başka deyişle yanlış okumalara neden olan şeyin okurun hazırlıklı oluşu olduğunu söyleyen Freud'dan alıntı yapan Venuti, Bass'in sözdizimini kaynak metindekine benzer, ancak ondan farklı bir anlam taşıyabilecek bir biçimde kurduğunu ve sonuçta ortaya çıkan yeni anlamın Derrida'nın söylediğinin zıttı olduğunu vurgular. Bu zıtlık, psikanalitik yaklaşımlar açısından önemlidir, çünkü Freud'a göre okur, metnin içerisinde savunma mekanizmasını harekete geçirecek şeyi yanlış okuma yoluyla düzeltir. Yani çevirinin olanaklılığına şüphe düşüren, çeviri sürecinde telafisi mümkün olmayan kayıpların kaçınılmazlığını dile getiren bir metin onu bir başka dile aktaran çevirmende rahatsızlık yaratıış, Bass ise yaptığı hatayla bilinçdışı bir şekilde çeviride herhangi bir kayıp olduğunu inkar etmiş olabilir (a.g.e.: 40).

Venuti'ye göre çevirmenin bilinçdışı metinseldir: erek dilin dışında varlığından söz edilemez, çeviri sürecinde o dil kullanıldığında varlığını gösterir. Çevirmen, kaynak metni aktarmak için bir gösteren zinciri üretirken, kendi bilinçdışı mekanizmasını açığa çıkaran bir "geriye kalan” ortaya koyar; fakat bu ancak o metinle, hatta o metnin belirli bir bölümüyle ilişkilidir. Ve bu "geriye kalan” çeşitli metinlerarası bağlantılar içerebilir. Venuti’nin belirttiği üzere, Lacan, gösterme zincirinin öznenin arzusunu doğuran bir eksiklik alanı olduğunu öne sürer. Arzu özneden değil, Lacan'ın “Öteki” dediği şeyden, öznenin dil edinimi sırasında içselleştirdiği gösterenlerden kaynaklanır. Buna özneyi arzulayan ilk kişi (yani anne) tarafından kullanılan gösterenler kadar, öznenin doyum isteğine bir yanıt beklediği gösterenler de dahildir. Öteki, sembolik düzendir, bir tanımlama süreciyle özneyi meydana getiren gösterme zinciridir. Bu meydana getirme dilde öznenin farkındalığı olmadan gerçekleşir. Lacan’ın deyişiyle, “bilinçdışı, Ötekinin söylemidir”; bir başka deyişle ise, "gösterenin Ötekindeki varlığı genellikle özneye kapalı bir varlıktır, çünkü bir bastırma durumunda ısrar eder". Çevirmenin durumunda ise arzunun üretildiği sahne kaynak metin gösterenleridir. Kaynak metin çevirmende bir eksiklik yaratır, çevirmen bilinçsizce bu metnin eksikliği doyurmasını ister ve doyuma ulaşmak için metni değiştirir. O halde çevirmenin arzusu, erek dilde yer değiştirmelerin yaşandığı ya da çevirinin kaynak metinden bir hatayla sonuçlanacak kadar uzaklaştı̆ğ durumlarda ortaya çıkar. Bu, çevirmenin arzusunun asla nesnesini bulamadığı, asla doyurulmadığı anlamına gelir. Çeviride yer değiştirme ve kaynak metinden uzaklaşma çevirmenin “düşlem”ini oluşturur; Lacan bunu “öznenin kendisini yok olma arzusu duyma noktasına getirdiği şey, bizzat isteğin doyuma ulaşmasının nesnesini kendisinden saklayacağı kadar yok olma” şeklinde tanımlamıştır (a.g.e.: 40). 
O halde, Derrida'nın Fransızca metni Bass' in çevirisinde bilinçdışı bir isteği, kaynak metnin tamamen çevrilebilir olması isteğini uyandırmıştır. Ancak bu istek Derrida'nın çevrilemezlik iddiasıyla reddedilmiştir. Bu ret çevirinin sözlüksel ve sözdizimsel düzeylerinde, Bass’ in İngiliz ve Amerikan felsefesini akla getiren terminoloji kullanımında ve çevrilebilirlik arzusunu su yüzüne çıkaran yanlış yorumlamasında kendisini gösterir. Bilinçdışında ortaya konan "geriye kalan”, Bass'in arzusunu doyuma ulaştıran ama gerçek hüsranını gözleyen bir düşlemdir (a.g.e.: 41).

Psikanalitik kuram bireysel psikolojiyi incelemeyi amaçlasa da, Venuti'nin bu kuramı çeviriye uygulaması, çevirmenin arzusunun tamamen kişisel olmadığını, muhtemelen pek çok farklı çevirmence paylaşıldığı düşünülürse aynı zamanda bireyötesi olduğunu göstermektedir. Mehlman ve Bass' in aynı hatayı yapmış olmaları buna örnektir. Bir çeviri metin bir çevirmenin belirli kaynak metinlere ve kültürlere ve bu metinlerdeki belirli bölümlere ilişkin arzularını ifade edebilir. Lacan'a göre arzu Ötekinden kaynaklandığına göre ve Öteki, öznenin deneyimindeki çeşitli insanları temsil ederek, tanımlama ve aktarma veya yerine koyma yoluyla sembolik bir işlev üstlendiğine göre, çevirmenin arzusunun da kültürel gelenekler ve toplumsal kurumlarca belirlenen kolektif biçimler alabileceğini kabul etmeliyiz. Böyle durumlarda çevirmenin arzusu sadece kişisel değil, politik de olabilir (a.g.e.: 41).

$\mathrm{Bu}$ örnekte gördüğümüz üzere, Venuti karşılaştı̆̆ çeviri hatasını sıradan bir hata olarak görüp göz ardı etmek yerine bu hatanın olası nedenleri üzerine fikir yürüterek bir çevirmen hatasını çeviribilimde psikanalitik yaklaşımın verimli ve aydınlatıcı olabileceğini vurgulamak amacıyla yapıcı bir biçimde kullanmıştır.

\section{Sonuç Gözlemleri}

Çeviri eylemini gerçekleştiren ve çeviri üzerine fikir yürüten iki önemli ismin, Vladimir Nabokov ve Lawrence Venuti'nin yukarıda detaylandırılan birbirinden farklı çeviri ve çeviri eleştirisi yaklaşımlarının sıradan bir okurdan ya da herhangi bir eleştirmenden beklenmeyecek iki çarpıcı uç örnek olduğu açıktır. Bu örneklerden biri çeviriye ve çevirmenlere üstten bakan, onları çeviri gerçeklerini göz önünde bulundurmaksızın acımasızca eleştiren sert bir yaklaşıma sahipken, diğeri gözden kaçabilecek kadar küçük bir çeviri hatasından yola çıkarak bu hatanın nedenleri üzerine derinlemesine düşününce ortaya çeviri ve çeviribilim açısından ne denli verimli bir bakış açısının çıkabileceğini göstermektedir. Çevirileri ve çevirmenleri kendi kıstasları uyarınca belirli kategorilere hapsettiği görülen Nabokov'un çeviri sürecinde özgün metni ve özgün metin yazarını ön planda tutan kararlar almayı yeğlemesi onun son derece kaynak odaklı bir yaklaşıma sahip olduğunu göstermektedir. Bu yaklaşım, kendi kaynak odaklı kıstaslarına uymadığı takdirde kendi yaptığı çeviriyi ortaya çıkarmayı reddeden Nabokov'un çeviriyi ve çevirmenleri özgün metne ve özgün metin yazarına kıyasla daha aşağı bir konumda gördüğünü hissettirmektedir. Bu bakış açısının günümüz çeviribilim yaklaşımlarından ne kadar uzak olduğu açıktır. Diğer yandan Venuti’nin bir çeviri eleştirisi olarak da okuyabileceğimiz çalışmasında 
kaynak ya da erek odaklılık gibi bir yaklaşım sezilmez. Venuti çeviride gözüne çarpan küçük bir hatayı bir çeviribilimci bakışıyla incelemiş ve bu hatanın altında yatıyor olabilecek nedenleri çeviri eyleminin doğasını da sorgulayan bir yaklaşımla irdeleyerek ortaya çeviribilim alanında başka çalışmalara kapı açabilecek kadar verimli bir çeviri eleştirisi çıkarmıştır.

Doğal olarak her okur - çevirmen - eleştirmen çeviri metni Nabokov’un yaptığı gibi son derece detaylı bir okumayla didiklemez; çeviriye dair bu denli idealist beklentilere de sahip değildir. Benzer şekilde, karşılaşılan her çeviri hatasının Venuti örneğindeki gibi yapıcı ve verimli tartışmalara yol açması beklenemez. Bu çalışmada yer verilen iki uç örnek, çeviri eleştirisinin ulaşabileceği iki uç noktayı sergileme amacı taşımaktadır. Dolayısıyla bu çalışmada ister sıradan bir okur, ister bir edebiyat figürü, isterse bir çeviribilim araştırmacısı olsun, çeviri eleştirisi yapmayı üstlenen kişinin çeviriye ilişkin her türlü gerçeği göz önüne almaya açık bir bakış açısı benimsemesinin pek çok farklı olasılığa da kapı açabileceğine işaret edilmektedir. Gerek akademik yayınlarda gerekse edebiyat dergilerinde yapıcı bir yaklaşımla kaleme alınmış çeviri eleştirilerine yer verilmesi çeviri metinlerin farkındalıkla okunmasını sağlayacak, daha iyi ve özenli çeviriler üretilmesine yol açacak ve belki de gelecekte yapılacak çeviri araştırmaları için yeni yaklaşımlar sunacaktır.

Hakem Değerlendirmesi: Dış bağımsız.

Çıkar Çatışması: Yazar çıkar çatışması bildirmemiştir.

Finansal Destek: Yazar bu çalışma için finansal destek almadığını beyan etmiştir.

Peer-review: Externally peer-reviewed.

Conflict of Interest: The author has no conflict of interest to declare.

Grant Support: The author declared that this study has received no financial support.

\section{KAYNAKÇA/REFERENCES}

Aksoy, B. (2001). “Çeviride çevirmen seçimleri 1şı̆̆ında çeviri eleştirisi”. Hacettepe Üniversitesi Edebiyat Fakültesi Dergisi, 18 (2), s. 1-16.

Boyd, B. (2010). Nabokov as Translator: Passion and Precision. Çevrimiçi kaynak: http://www.revistas.usp. br/rus/article/download/88678/91555/ Son erişim 09.10.2019.

Ece, A. (2008). “Çeviri Eleştirisinde Yaklaşımlar”, Çeviri Seçkisi I: Çeviriyi Düşünenler, 2. Bsm., Haz. Mehmet Rifat, s. 137-147, İstanbul: Sel Yayıncılık.

Ece, A. (2016). Çevirmenin Yazar ve Kahraman Olarak Portresi. İstanbul: Çeviribilim Yayınları.

Göktürk, A. (1986). Çeviri: Dillerin dili. İstanbul: Çağdaş Yayınları.

Hizır, N. (1943). “Tercüme tenkitleri hakkında”. Tercüme, 4 (20-21), s. 177-178.

İnce, Ü. (1993). “Çeviriyi eleştirmeden önce”. Dilbilim Araştırmaları 1993, s.5-11.

İnce, Ü. (2019). Çeviri Bilinci - Çevirenler, Çeviremeyenler, Çeviriverenler. İstanbul: Tekin Yayınevi.

Karantay, S. (1993). “Çeviri Eleştirisinin Bilimsel Konumu Üzerine Eleştirel Görüşler ve Bir Model Önerisi”. Dilbilim Araştırmaları Dergisi, 4, s. 17-24.

Nabokov, V. (1990). Eugene Onegin: A Novel in Verse (Text). Bollingen Series, Princeton University Press, $2^{\text {nd }}$ ed. 
Nabokov, V. (2012). "Problems of Translation: Onegin in English." Lawrence Venuti ed., The Translation Studies Reader içinde. Routledge, 3rd ed., s. 113-25.

Nabokov, V. (2013). Rus Edebiyatı Dersleri, (Çev. Yiğit Yavuz, Fatih Özgüven, Ayşe Nihal Akbulut), İletişim Yayınları, İstanbul.

Paker, S. (1983). “Çeviride 'yanlı̧̧/doğru’ sorunu ve şiir çevirisinin değerlendirilmesi”. Yazko Çeviri, 13, s. 131-139.

Venuti, L. (2013). Translation changes everything: Theory and practice. London: Routledge.

Yücel, F. (2007). “Çeviri Eleştirisi Neyi Eleştirir?” Uludağ Üniversitesi Fen-Edebiyat Fakültesi Sosyal Bilimler Dergisi, 8 (12), s. 39-58. 
